УДК 633.11 (321). 003.13

(C) 2016

Рожков А. О., доктор сільськогосподарських наук,

Бобро М. А., доктор сільськогосподарських наук,

Рижик Т. В., асистент

Харківський національний аграрний університет ім. В. В. Докучаєва

\title{
ФОРМУВАННЯ ПРОДУКТИВНОСТІ КОЛОСА РОСЛИН ПШЕНИЦІ ОЗИМОЇ ЗАЛЕЖНО ВІД СТРОКУ СІВБИ ТА НОРМИ ВИСІВУ
}

\section{Рецензент - доктор сільськогосподарських наук Т. І. Гопцій}

У статті представлені результати досліджень, проведених протягом 2007-2009, 2014 рр. на дослідному полі ХНАУ ім. В. В. Докучаєва щзодо впливу застосування різних строків сівби та норм висіву на варіабельність показників продуктивності колоса різних систем стебел пшениці м'якої озимої сорту Астет. Формування вищих показників продуктивності колоса головної $і$ бічної системи стебел у середньому за роками досліджень забезпечувала сівба 1517 вересня з нормою висіву 5,0 млн нас./2а. Ефективність чинника норми висіву за роками досліджень була більш сталою порівняно зі строками проведення сівби, вплив яких значно залежав від погодних умов вететаційного періоду конкретного року досліджень.

Ключові слова: пшениця м'яка озима, норма висіву, строки сівби, озерненість колоса, система стебел, маса зерна з колоса.

Постановка проблеми. Урожай зернових хлібів визначається кількістю колосоносних стебел на одиницю площі та продуктивністю їх колосся. Тому важливо знати, під впливом яких чинників формується продуктивність колоса. Особливої уваги заслуговують питання впливу контрольованих чинників на розвиток колоса різних систем стебел, оскільки вони відіграють значну роль у формуванні врожайності рослин. Значний інтерес представляє вивчення впливу агротехнічних чинників: норм висіву та способів сівби на особливості формування зернової продуктивності колоса.

Аналіз останніх досліджень і публікацій, у яких започатковано розв'язання проблеми. Більшість вітчизняних і зарубіжних учених відмічають важливу роль строків проведення сівби у формуванні продуктивності як конкретних рослин, так і посівів у цілому $[9,15,19]$.

Дослідженнями встановлено, що для кожної агрокліматичної зони правильно підібрані строки сівби пшениці озимої мають важливе значення як у сприятливі, так i несприятливі роки. Проте в науковій літературі трапляються досить різні рекомендації $[1,2,6,16,17]$.
Встановлено, що різні за біологічними ознаками сорти по-різному реагують на строки сівби $[2,4]$. Сорти 3 підвищеною фотоперіодичною реакцією та зимостійкі слід висівати раніше, а 3 короткою стадією яровизації на 5-10 днів пізніше сортів, які мають тривалу стадію яровизації [20].

Більшість вчених стверджують, що зміщення строків сівби від оптимальних як у бік ранніх, так і у бік пізніх, без урахування особливостей року та сорту неухильно веде до зниження врожайності зерна пшениці озимої. На думку багатьох учених, перегляд основних агротехнічних заходів повинен відбуватися щонайменше один раз на 10 років, а оптимальні строки сівби пшениці озимої слід змістити на 10-15 днів пізніше, ніж вони були 10-15 років тому $[11,18,21]$.

У системі агротехнічних прийомів вирощування пшениці озимої на основі адаптивного рослинництва важливу роль відіграють норми висіву, від чого суттєво залежать ріст, розвиток $\mathrm{i}$ продуктивність рослин [8]. Постійне сортооновлення та створення нових інтенсивних сортів пшениці озимої, зміни погодних умов, а також у зв'язку з різким зменшенням обсягів внесення органічних та мінеральних добрив, актуальним питанням є вивчення оптимальної норми висіву пшениці особливо по пару.

Для створення високопродуктивного посіву пшениці озимої важливо сформувати оптимальну густоту рослин і рівномірно розмістити їх на площі. Адже для нормального росту і розвитку рослинам потрібна відповідна площа живлення, за якої вони будуть мати достатню кількість поживних речовин і води для створення необхідної вегетативної маси і формування зерна [3].

Необгрунтоване зменшення норми висіву знижує врожайність більше, ніж іiі завищення, оскільки в результаті сильного кущіння утворюється велика кількість підгону, який не формує зерна або утворює дрібне зерно і формується недостатня кількість продуктивних стебел $[13,17]$. 
Оптимальна норма висіву не є величиною постійною - вона залежить від багатьох чинників і передусім від якості насіння, сорту, строку і способу сівби, грунтово-кліматичних умов, попередника, вологості й родючості грунту тощо. Водночас для різних зон, сортів і строків сівби 3 урахуванням агрофізичних властивостей грунту й вологозабезпеченості оптимальними нормами висіву вважаються від 400 до 700 схожих насінин на $1 \mathrm{~m}^{2}[2,10]$.

Норми висіву тісно пов'язані зі строками сівби. За сівби у ранні строки рослини добре кущаться й оптимальний стеблостій формується за менших норм висіву - по пару 3,0-4,0 млн шт./га; після непарових попередників - 4,0-4,5 млн шт./га. В оптимальні строки сівби пшеницю озиму краще висівати 3 нормою висіву 4-4,5 і 5,0 млн шт./га відповідно. За пізніх строків сівби рослини восени не кущаться, тому для створення оптимальної густоти стеблостою норму висіву необхідно збільшувати до 5,5-6,0 млн схожих насінин на гектар 3 тим, щоб навесні нараховувалось не менше 300 рослин на 1 м $^{2}[13,17]$.

Таким чином, норма висіву пшениці озимої не $\epsilon$ сталою величиною, а змінюється залежно від якості насіння, сорту, попередника, строку сівби, фракції насіння, вологості й родючості грунту та інше. Норми висіву потрібно щороку уточнювати не тільки в межах області та району, а й у кожному господарстві та встановлювати для кожного поля окремо, залежно від грунтовокліматичних умов та інших конкретних обставин.

Мета досліджень полягала у визначенні ефективності застосування різних строків сівби та норм висіву на варіабельність показників продуктивності колосся різних систем стебел пшениці м'якої озимої сорту Астет.

Завдання досліджень. Відповідно до поставленої мети було передбачено визначення показників продуктивності колоса головної системи стебел та системи бічних стебел I порядку пшениці озимої сорту Астет, а саме: кількості колосків у колосі, озерненості колоса, його маси, залежно від впливу досліджуваних чинників. Окрім цього було заплановано визначення часток досліджуваних чинників у варіабельність досліджуваних показників.

Методика досліджень. Для вирішення поставленого завдання було проведено польовий дослід методом розщеплених ділянок на дослідному полі ХНАУ ім. В. В. Докучаєва впродовж 20072009, 2014 рр. за загальнопоширеною методикою [5]. Ділянками першого порядку були такі варіанти строків сівби: 5-7 вересня (контроль); 15-17 вересня; 25-27 вересня. Ділянками другого по- рядку були чотири варіанти норми висіву: 4,0; 4,5; 5,0 і 5,5 млн нас./га. Дослід було закладено у чотирикратній повторності, загальна кількість ділянок другого порядку становила 12 штук. Площа елементарної облікової ділянки $-45 \mathrm{~m}^{2}$.

Агротехніка, що застосовувалася у досліді, була загальноприйнятою для зони східного Лісостепу України, крім елементів технології, що досліджувалися.

Грунт дослідного поля - чорнозем типовий важкосуглинковий на карбонатному лесі. В орному шарі грунту міститься 4,4-4,7 \% гумусу, 13,8 мг рухомого фосфору, 10,3 мг калію на 100 г грунту.

Регіон проведення досліджень має характер нестійкого зволоження. Середньобагаторічна сума опадів за рік становить близько 530 мм: від 250 мм у гостропосушливі роки до 800 мм у роки 3 надмірною кількістю опадів. Сумарна кількість опадів у період перед початком відновлення вегетації (січень, лютий) і за період веснянолітньої вегетації пшениці м’якої озимої (березень-липень) у 2007, 2009 та 2014 рр. (відповідно $262,6,275,3$ і 305,7 мм) була близькою до середньобагаторічного показника, який становить близько 286 мм. За режимом зволоження кращими були погодні умови 2008 року. Кількість опадів за вказаний період була на $12 \%$ більшою порівняно із середніми багаторічними показниками, до того ж розподіл опадів за цей період у 2008 р. був найбільш сприятливий для реалізації генетичного потенціалу продуктивності колоса рослин пшениці озимої.

За температурним режимом погодні умови другої половини вегетації, особливо в 2014 р., характеризувалися значним підвищенням рівня цього показника порівняно з багаторічними показниками. Відмічені підвищення температурного режиму вносили істотні корективи у процеси росту і розвитку, формування зернової продуктивності рослин. Встановлене значне коливання метеорологічних показників упродовж років досліджень дало змогу більшою мірою виявити вплив досліджуваних елементів технології на рівень зернової продуктивності рослин.

Результати досліджень. Основними компонентами колоса, які беруть участь у формуванні врожаю, є кількість колосків і зерен у колосі (шт.) і маса зерна з одного колоса (г). Формування колоса пшениці озимої відбувається 3 III по VIII етап органогенезу, тому його величина, кількість колосків і зерен у ньому залежать від зовнішніх умов у цей період, найважливішими 3 яких є температура і тривалість дня [7].

Визнаючи домінуючу роль погодних умов пе- 


\section{СІЛЬСЬКЕ ГОСПОДАРСТВО. РОСЛИННИЦТВО}

ріоду вегетації не слід не дооцінювати роль агрозаходів на формування продуктивності колоса рослин. Проведені нами дослідження довели ефективність досліджуваних чинників на варіабельність зернової продуктивності колосся різних систем стебел рослин пшениці м'якої озимої. У середньому за чотири роки досліджень істотного впливу строків сівби на варіабельність показників зернової продуктивності обох систем стебел рослин пшениці озимої не відзначено, водночас була відмічена позитивна тенденція проведення сівби 15-17 вересня для підвищення досліджуваних показників (див. табл.).

Густота посіву значно впливає на формування колосків і квіток у колосі [14]. У результаті наших досліджень встановлено, що зі збільшенням норми висіву насіння 3 4,0 до 5,5 млн шт./га кількість колосків у колосі головного стебла в середньому за роками досліджень істотно зменшува- лася на 0,6-0,7 шт. залежно від строку сівби. Водночас найбільше зниження цього показника було у випадку підвищення норми висіву до максимальної - від 5,0 до 5,5 млн нас./га - на 0,4 шт./колоса.

Аналогічна ситуація відмічена і за колоссям стебел першого порядку. Так, зі збільшенням норми висіву 3 4,0 до 5,5 млн нас./га кількість продуктивних колосків у колосі цієї системи стебел зменшувалася в середньому за чотири роки досліджень на 0,6 шт./колоса за HIP 05 ефекту чинника - 0,2 шт./колоса.

За обох досліджуваних чинників більша озерненість колоса різних систем стебел забезпечувалася за рахунок більшої кількості продуктивних колосків у колосі. Впливу досліджуваних варіантів елементів технології вирощування на озерненість колоска у колосі різних систем стебел не було.

Показники продуктивності колоса різних систем стебел пиениці озимої сорту Астет залежно від строку сівби та норми висіву (середнс за 2007-2009, 2014 рр.)

\begin{tabular}{|c|c|c|c|c|c|c|c|}
\hline \multirow[t]{2}{*}{$\begin{array}{c}\text { Строк } \\
\text { сівби (А) }\end{array}$} & \multirow{2}{*}{$\begin{array}{c}\text { Норма } \\
\text { висіву (В), } \\
\text { млн нас./га }\end{array}$} & \multicolumn{2}{|c|}{$\begin{array}{c}\text { Продуктивних } \\
\text { колосків у } \\
\text { колосі, шт. }\end{array}$} & \multicolumn{2}{|c|}{$\begin{array}{l}\text { Озерненість } \\
\text { колоса, шт. }\end{array}$} & \multicolumn{2}{|c|}{$\begin{array}{c}\text { Маса зерна } 3 \\
\text { колоса, г }\end{array}$} \\
\hline & & $\Gamma \mathrm{C}^{*}$ & БC** & $\Gamma^{*} *$ & БC** & $\Gamma \mathrm{C}^{*}$ & БC** \\
\hline \multirow{4}{*}{$\begin{array}{c}\text { 5-7 вересня } \\
\text { (перший) } \\
\text { контроль }\end{array}$} & $4,0(\kappa)$ & 16,9 & 15,0 & 29,9 & 24,4 & 1,24 & 0,94 \\
\hline & 4,5 & 16,9 & 14,8 & 30,0 & 24,3 & 1,26 & 0,93 \\
\hline & 5,0 & 16,5 & 14,8 & 26,2 & 24,1 & 1,21 & 0,92 \\
\hline & 5,5 & 16,2 & 14,6 & 25,6 & 23,2 & 1,18 & 0,88 \\
\hline \multirow{4}{*}{$\begin{array}{c}\text { 15-17 вересня } \\
\text { (другий) }\end{array}$} & 4,0 & 16,9 & 15,3 & 30,3 & 24,5 & 1,25 & 0,95 \\
\hline & 4,5 & 16,9 & 15,4 & 30,1 & 24,6 & 1,25 & 0,95 \\
\hline & 5,0 & 16,6 & 15,0 & 29,8 & 23,9 & 1,23 & 0,91 \\
\hline & 5,5 & 16,2 & 14,6 & 28,5 & 22,8 & 1,17 & 0,87 \\
\hline \multirow{4}{*}{$\begin{array}{l}\text { 25-27 вересня } \\
\text { (третій) }\end{array}$} & 4,0 & 16,8 & 15,2 & 29,9 & 24,2 & 1,24 & 0,93 \\
\hline & 4,5 & 16,7 & 15,1 & 29,7 & 24,1 & 1,23 & 0,92 \\
\hline & 5,0 & 16,7 & 15,0 & 29,3 & 23,6 & 1,21 & 0,90 \\
\hline & 5,5 & 16,3 & 14,5 & 28,4 & 22,8 & 1,17 & 0,86 \\
\hline \multirow{3}{*}{$\begin{array}{c}\text { Середнє за } \\
\text { строками сівби }\end{array}$} & перший & 16,6 & 14,8 & 29,4 & 24,0 & 1,22 & 0,92 \\
\hline & другий & 16,7 & 15,1 & 29,7 & 23,9 & 1,23 & 0,92 \\
\hline & третій & 16,5 & 15,0 & 29,3 & 23,7 & 1,21 & 0,90 \\
\hline \multirow{4}{*}{$\begin{array}{c}\text { Середнє за } \\
\text { нормами висіву }\end{array}$} & $4,0(\boldsymbol{\kappa})$ & 16,9 & 15,2 & 30,1 & 24,4 & 1,24 & 0,94 \\
\hline & 4,5 & 16,8 & 15,1 & 30,0 & 24,3 & 1,25 & 0,93 \\
\hline & 5,0 & 16,6 & 14,9 & 29,4 & 23,9 & 1,22 & 0,91 \\
\hline & 5,5 & 16,2 & 14,6 & 28,5 & 22,9 & 1,17 & 0,87 \\
\hline \multicolumn{2}{|c|}{ Середнє по досліду } & 16,6 & 14,9 & 29,5 & 23,9 & 1,22 & 0,91 \\
\hline \multicolumn{2}{|c|}{ HIP $_{05}$ головного ефекту А } & 0,2 & 0,6 & 0,7 & 0,7 & 0,04 & 0,04 \\
\hline \multicolumn{2}{|c|}{$\mathrm{HIP}_{05}$ головного ефекту В } & 0,1 & 0,2 & 0,4 & 0,4 & 0,01 & 0,01 \\
\hline \multicolumn{2}{|c|}{$\mathrm{HIP}_{05}$ часткових порівнянь А } & 0,6 & 1,1 & 1,5 & 1,3 & 0,08 & 0,07 \\
\hline \multicolumn{2}{|c|}{ HIP $_{05}$ часткових порівнянь В } & 0,2 & 0,4 & 0,7 & 0,7 & 0,03 & 0,02 \\
\hline
\end{tabular}

Примітка: ГС* - головне стебло; БС** - бічне стебло першого порядку. Під час розрахунків НІР 05 роки досліджень приймали за повторення. 


\section{СІЛЬСЬКЕ ГОСПОДАРСТВО. РОСЛИННИЦТВО}

Істотне зниження всіх досліджуваних показників залежно від впливу норми висіву мало місце лише за ії збільшення з 4,0 до 5,0 млн нас./га. Збільшення норми висіву з 4,0 до 4,5 млн нас./га не викликало істотного зниження жодного 3 досліджуваних показників. Тож, логічно зробити припущення, що підвищення норми висіву до 4,5 млн нас./га - це цілком виправдано, адже зернова продуктивність 3 одиниці площі за рахунок збільшення кількості рослин без істотного зниження показників зернової продуктивності окремої рослини зростатиме.

На думку В. В. Лихочвора [12], набагато ширші можливості росту врожайності закладені у показнику маси зерна $з$ одного колоса. Адже саме добуток кількості продуктивних стебел та маси зерна $з$ одного колоса визначені перед збиранням, дають нам величину біологічного врожаю. У наших дослідженнях збільшення норми висіву сприяло закономірному зменшенню маси зерна 3 одного колоса обох систем стебел. Так, за норми висіву 4,0 млн нас./га маса зерна 3 колоса головного стебла в середньому за роками досліджень та строками сівби становила 1,24 г, 4,5-1,25 г, 5,01,22 г, 5,5-1,17 г. Діапазон мінливості маси зерна 3 колоса головної системи стебел залежно від впливу норми у середньому за чотири роки досліджень становив 0,08 г (6,8 \%) за $\mathrm{HIP}_{05}-0,01$ г.
Ще вищою ефективність норми висіву проявлялася на варіабельності маси зерна 3 колоса системи стебел першого порядку. Так, зі збільшенням норми висіву з 4,0 до 5,5 млн нас./га маса зерна 3 колоса бічного стебла зменшувалася на $8,0 \%$. Унаслідок загострення конкуренції маса зерна 3 колоса обох систем стебел найбільше зменшувалася 3 підвищенням норми висіву з 5,0 до 5,5 млн нас./га.

У проведених дослідженнях варіабельність кількості продуктивних колосків у колосі як головної, так і бічної системи стебел більшою мірою залежала від впливу норми висіву. Ця тенденція відзначалася в більшості років. Лише в 2008 р. ефективність цього чинника була меншою порівняно зі строком сівби. Так, частка норми висіву у варіабельність кількості продуктивних колосків у колосі головного стебла в 2007, 2008, 2009 і 2014 рр. відповідно становила 44,3; 14,0; 45,5 і $41,7 \%$ (рис. 1).

Частка строків сівби у варіабельності кількості продуктивних колосків у колосі була більшою в більш сприятливих погодних умовах 2008 i 2014 років. Зокрема, вклад строків сівби у мінливість кількості продуктивних колосків у колосі головного стебла у 2007, 2008, 2009 і 2014 pp. становив відповідно 3,3, 64,0, 6,5 і 6,9 \%, бічних $-12,2,14,0,5,0$ i $18,8 \%$.

\section{Головні стебла}

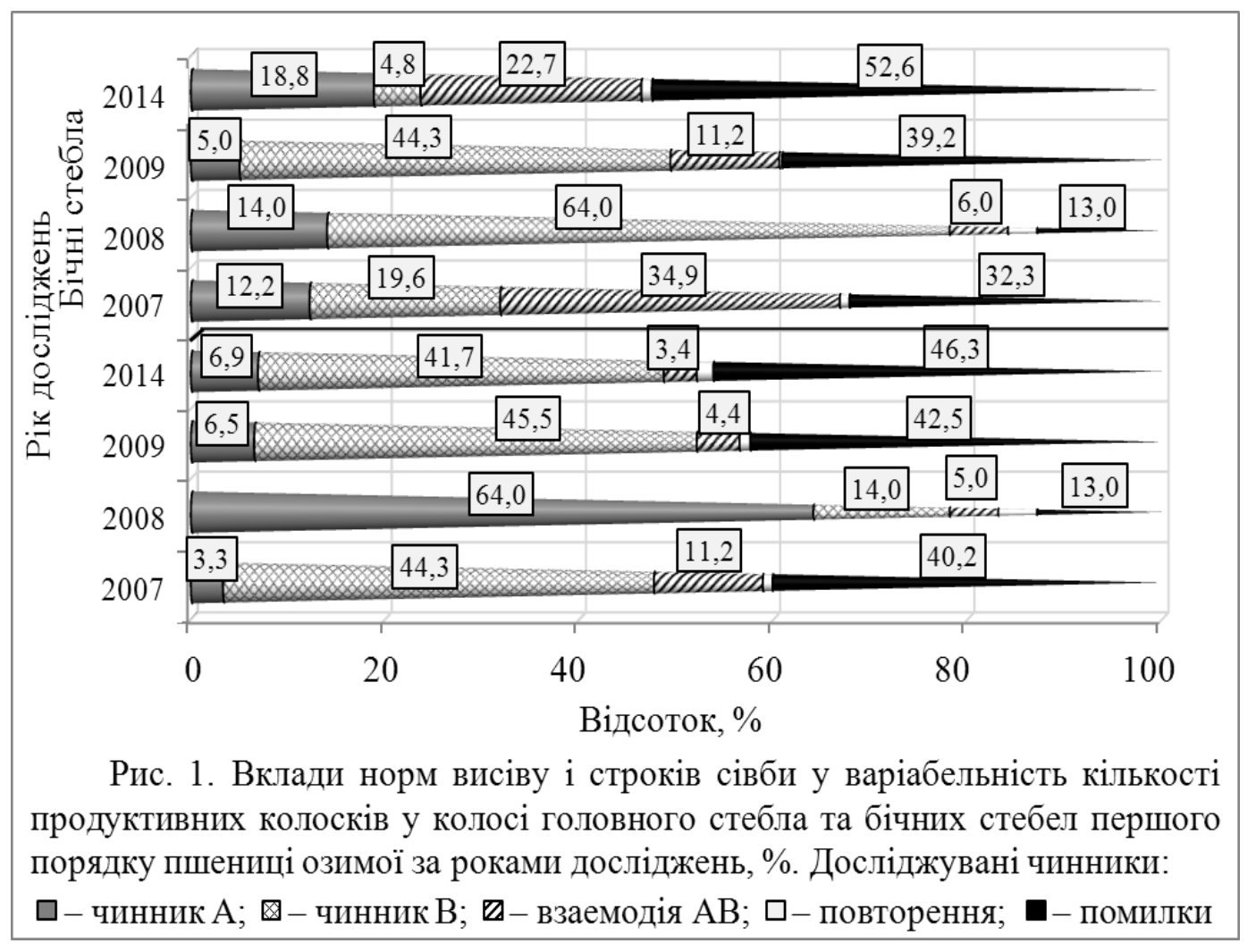




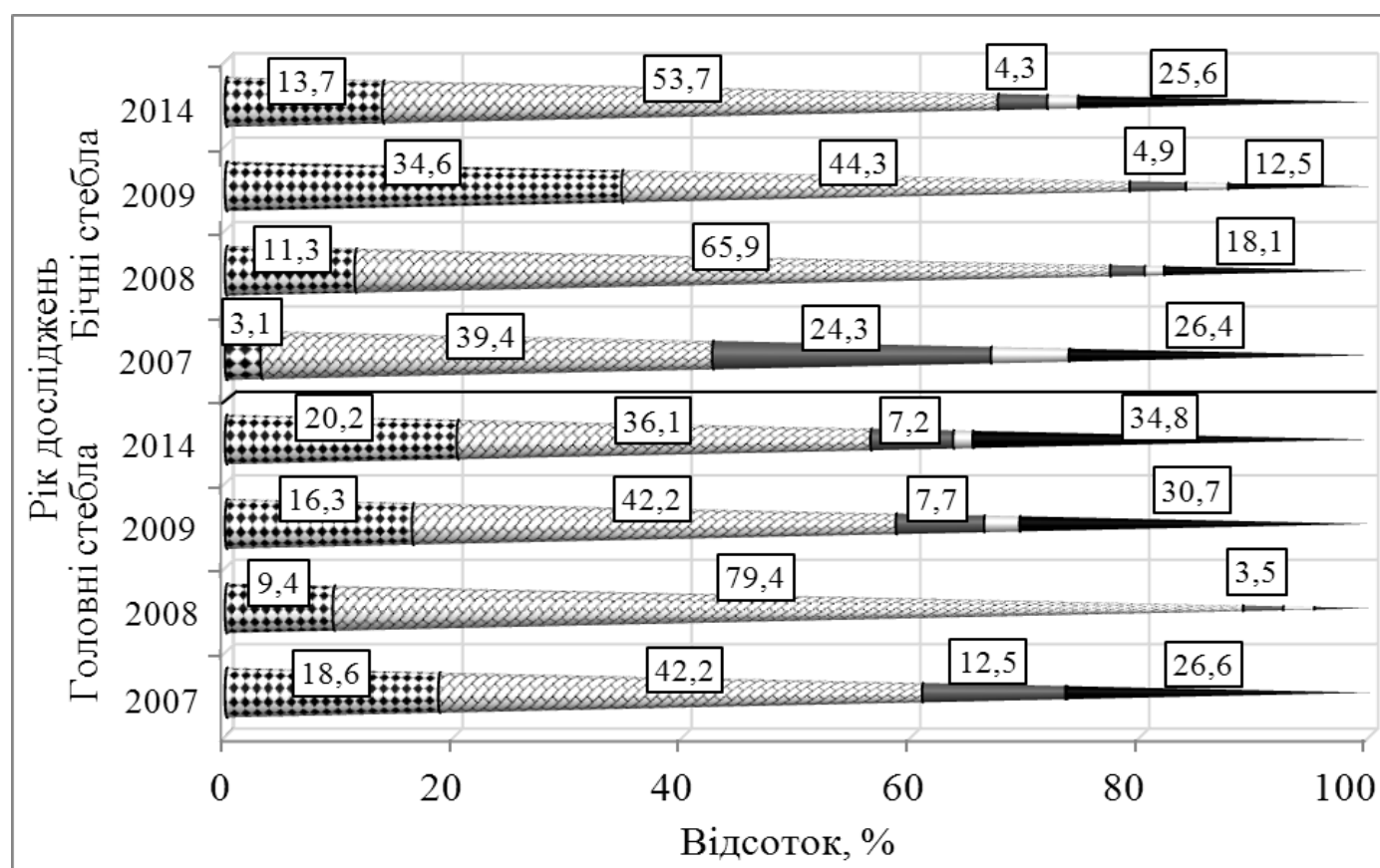

Рис. 2. Вклади норми висіву і строків сівби у варіабельність озерненості колоса головного стебла та стебла першого порядку пшениці озимої за роками досліджень, \%. Досліджувані чинники:

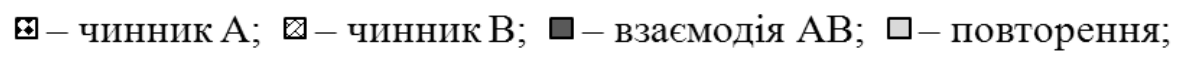

помилки

Частка взаємодії строків сівби та норми висіву більшою мірою проявлялася на зміні показників кількості продуктивних колосків у колосі стебел першого порядку. Найбільшою до того ж достовірною вона була в погодних умовах 2007 і 2014 pp. відповідно - 34,9 і 22,7\%.

Мінливість озерненості колоса обох систем стебел, як і мінливість кількості продуктивних колосків у колосі, більшою мірою залежала від впливу норми висіву. Вклад цього чинника у варіабельність озерненості колоса головного стебла у 2007, 2008, 2009 і 2014 рр. відповідно становив 42,$2 ; 79,4 ; 42,2$ і $36,1 \%$ (рис. 2).

Частка строків сівби у мінливості озерненості колоса головного стебла у 2007, 2008, 2009 i 2014 рр. становила відповідно 18,6, 9,4, 16,3 і $20,2 \%$, бічного - 3,1, 11,3, 34,6 і 13,7\%.

Частка взаємодії строків сівби та норми висіву у мінливості озерненості колоса стебла першого

\section{БІБЛІОГРАФІЯ}

1. Виблов Б. Р. Озима пшениця в Присивашші / Б. Р. Виблов, А. В. Виблова, М. І. Пихтін // Бюл. Ін-ту зерн. госп. - 2007. - №26-27. - С. 6770.

2. Влох В. Г. Рослинництво : підручник / [за ред. В. Г. Влоха, С. В. Дубковецького, Г. С. Кияка, Д. М. Онищук]. - К. : Вища школа, 2005. - порядку була істотною лише в 2007 р. - 24,3\%. За рештою років була відмічена лише тенденція взаємодії цих чинників.

Висновок. Встановлені нами закономірності зміни показників зернової продуктивності колосся різних систем стебел дають можливість контролювати технологічними елементами: строком сівби та нормою висіву, прогнозувати реалізацію генетичного потенціалу колоса пшениці м'якої озимої і формувати відповідні умови для його максимальної реалізації.

3 метою повнішого розкриття генетичного потенціалу продуктивності колосся, що належать до різних систем стебел, на підставі отриманих результатів досліджень, після чистого пару доцільно рекомендувати проводити сівбу пшениці озимої у другій декаді вересня нормою висіву $4,5-$ 5,0 млн нас./га.

$382 \mathrm{c}$.

3. Вожегова Р. Практика показує, що обмаль вологи в зоні Південного Степу можна компенсувати розміщенням озимої пшениці по чорному пару / Р. Вожегова, С. Заєць, А. Коваленко // Зерно і хліб. - 2013. - №4. - С. 36-38.

4. Вожегова P. A. Урожайність різних сортів 
пшениці озимої залежно від строків сівби в умовах Південного Степу / Р. А. Вожегова, С. О. Заєць, О. А. Коваленко // Вісн. аграр. науки. 2013. - C. 26-29.

5. Доспехов Б. А. Методика полевого опыта (с основами статистической обработки результатов исследований) / Б. А. Доспехов. - М. : Агропромиздат, 1985. - $305 \mathrm{c}$.

6. Друзяк В. Г. Урожайність і якість насіння пшениці озимої залежно від строків сівби / В. Г. Друзяк, О. В. Гавура // Вісн. аграр. науки півд. регіону. - 2008. - №8. - С. 60-63.

7. Зінченко О. I. Рослинництво: практикум / О. І. Зінченко, А. В. Коротєєв, С. М. Каленська ; за ред. О. І. Зінченка. - Вінниця : Нова книга, 2008. -536 c.

8. Гудзь В. П. Землеробство з основами агрохімії : підруч. [для студентів вищ. навч. закл.] / В. П. Гудзь, А. П. Лісовал, В. О. Андрієнко. - К. : Центр учбової літератури, 2007. - 408 с.

9. Зубеиьь М. В. Наукові основи агропромислового виробництва в зоні Степу України / М. В. Зубець. - К. : Аграрна наука, 2010. - 986 с.

10. Калиненко И. Г. Новое в агротехнике возделывания озимой пшеницы в засушливых условиях Ростовской области / И. Г. Калиненко. Ростов-на-Дону : Терра, 1999. - 39 с.

11. Зміна клімату і оптимізація строку сівби озимої пшениці / [Красиловець Ю. Г., Кузьменко Н. В., Скляровський К. М. та ін.] // Вісн. агpap. науки. - 2009. - №11. - С. 16-19.

12. Лихочвор В. Продуктивність колоса озимої пшениці [Електронний ресурс] / В. Лихочвор, С. Костючко // Агробізнес. - 2010. - №14-16. Режим доступу : http://www.agro-business.com.ua/ 2010-06-11-12-53-00/542-2011-07-07-09-36-03.html.

13. Лихочвор В. В. Рослинництво. Сучасні інтенсивні технології вирощування основних польових культур / В. В. Лихочвор, В. Ф. Петриченко. - Львів : НВФ «Українські технології», 2006. $-730 \mathrm{c}$.

14. Натрова 3. Продуктивность колоса зерновых культур / 3. Натрова, Я. Смочек. - М. : Колос, 1983. $-45 \mathrm{c}$.

15. Hеmic I. T. Наукове обгрунтування та розробка енергозберігаючих технологій вирощування озимої м'якої і твердої пшениці на зрошуваних землях півдня України : автореф. дис. на здобуття наук. ступеня д.с.-г.н. : спец. 06.01.09 «Рослинництво» / I. Т. Нетіс. - Херсон, 1998. $34 \mathrm{c}$.

16. Hemic I. T. Посухи та їх вплив на посіви озимої пшениці / І. Т. Нетіс. - Х. : Айлант, 2008. $252 \mathrm{c}$.

17. Hemic I. T. Пшениця озима на півдні України : монографія / I. Т. Нетіс. - Херсон : Олдіплюс, 2011. - 460 с.

18. Рудник-Іващуенко О. І. Особливості вирощування озимих культур за умов змін клімату / О. І. Рудник-Іващенко // Сортовивчення та охорона прав на сорти рослин. - 2012. - №2 . - С. 810.

19. Ташилов $X$. С. Агрономическая и технологическая оценка новых сортов озимой пшеницы в засушливых условиях степной зоны Кабардино-Балкарии : дис. ... к.с.-г.н. : 06.01.09 / Хасанбий Султанович Ташилов. - К., 2009. - 165 с.

20. Федосеев A. П. Соблюдение оптимальных сроков сева озимых - резерв повышения эффективности минеральных удобрений / А. П. Федосеев // Земледелие. - 1980. - №8. - С. 48-49.

21. Черенков A. В. Вплив кліматичних змін на строки сівби пшениці озимої в умовах північного Степу / А. В. Черенков, М. М. Солодушко, О. М. Козельський // Агроном. - №3. - 2014. C. $80-84$. 